\title{
The Good and the Bad of Cell Membrane Electroporation
}

\author{
Katja Balantičč, ${ }^{1,2}$ Damijan Miklavčičc, ${ }^{1}$ Igor Križaj ${ }^{3, \star}$ and Peter Kramar ${ }^{1, \star}$ \\ ${ }^{1}$ University of Ljubljana, Faculty of Electrical Engineering, Tržaška cesta 25, Ljubljana, Slovenia \\ ${ }^{2}$ University of Ljubljana, Medical Faculty, Vrazov trg 2, Ljubljana, Slovenia \\ ${ }^{3}$ Jožef Stefan Institute, Department of Molecular and Biomedical Sciences, Jamova cesta 39, Ljubljana, Slovenia \\ *Corresponding author: E-mail: igor.krizaj@ijs.si (I. Križaj); \\ peter.kramar@fe.uni-lj.si (P.Kramar)
}

Received: 10-11-2021

\begin{abstract}
Electroporation is used to increase the permeability of the cell membrane through high-voltage electric pulses. Nowadays, it is widely used in different areas, such as medicine, biotechnology, and the food industry. Electroporation induces the formation of hydrophilic pores in the lipid bilayer of cell membranes, to allow the entry or exit of molecules that cannot otherwise cross this hydrophobic barrier. In this article, we critically review the basic principles of electroporation, along with the advantages and drawbacks of this method. We discuss the effects of electroporation on the key components of biological membranes, as well as the main applications of this procedure in medicine, such as electrochemotherapy, gene electrotransfer, and tissue ablation. Finally, we define the most relevant challenges of this promising area of research.
\end{abstract}

Keywords: Electroporation; cell membrane; electrochemotherapy; gene electrotransfer; tissue ablation; nanotechnology

\section{Introduction}

Cell membrane electroporation, also known as electropermeabilization, ${ }^{1}$ is an effective method for internalization of various molecules into biological cells, with increasing number of applications in oncology, ${ }^{2,3}$ gene therapy, ${ }^{4-6}$ tissue ablation, ${ }^{7-9}$ food technology ${ }^{10,11}$ and nanotechnology. ${ }^{12}$

Electroporation depends on the nature of the molecular constituents of biological membranes and their behavior in electric field. The first part of this article thus dissects out the structure of the cell membrane and describes the main transport mechanisms across this barrier. In the second part, the mechanistic principles of electroporation are presented, followed by a description of the influence of an externally applied electric field on specific cell-membrane components, such as lipids and proteins, as well as the cytoskeleton. Finally, the advantages, disadvantages, and remaining challenges of electroporation are critically discussed.

\section{1. Structure of the Cell Plasma Membrane}

The plasma membrane is basically a $6-10 \mathrm{~nm}$-thick biological structure that surrounds every living cell, and it provides a selective barrier between the intracellular and extracellular environments. ${ }^{13}$ Plasma membrane thickness of some cells can however be much larger than this basic value, for example due to glycocalyx, a highly charged layer of membrane-bound biological macromolecules attached to the membrane (e.g., endothelial and epithelial cells), or the membrane skeleton, a specialized part of the cytoskeleton closely coupled to the plasma membrane. The main function of the plasma membrane is to keep the constituents of the cell inside, while preventing unwanted substance to enter the cell. At the same time, it mediates the selective transport of essential nutrients into the cell, and of waste products in the opposite direction. ${ }^{14}$

The cell membrane provides a selective barrier due to its unique structure, which consists mainly of amphiphilic phospholipid molecules. These form a continuous double layer (the 'phospholipid bilayer') that has a profoundly hydrophobic core. The proteins embedded in or associated with this structure endow it with specific functions, such as the selective passage of molecules and ions. Cell shape is primarily determined by interactions between the cell-membrane components, the cytoskeleton, and the extracellular matrix, ${ }^{14,15}$ however factors contributing to the cell shape are much more complex. ${ }^{16-19}$ 
As well as the major lipid constituents of the plasma membrane, the phospholipids, there are two other lipid species that are very important: sterols and glycolipids. ${ }^{20}$ Cholesterol is the main sterol-based lipid molecule in the plasma membrane. It is intercalated between the lipid tails of the adjacent phospholipid molecules in the phospholipid bilayer thus increasing their ordering. In this way, it reduces membrane fluidity. ${ }^{15,21}$ Glycolipids (e.g., gangliosides) are very important cell-surface markers that serve as specific determinants for cellular recognition and cell-tocell communication, and as receptors for different biomolecules. The fatty acid chains in the phospholipids and glycolipids usually contain an even number of carbon atoms, and can be saturated or unsaturated, i.e., they can contain one or more double bonds. The length of a fatty-acid chain and the number of double bonds that it contains have profound effects on the internal energy of the cell membrane; i.e., on its order and fluidity. ${ }^{13}$

\section{2. Molecular Transport Through the Plasma Membrane}

The cell plasma membrane is selectively permeable, whereby the passage into the cell of molecules needed for its survival is highly regulated. The transport of molecules through the plasma membrane can be passive or active. Passive transport does not require energy, and its rate is governed by the physicochemical properties of the cell membrane, visco-elastic properties on both sides of the membrane, physicochemical and electrical properties of the media on both sides of the membrane, and the molecules to be transported. ${ }^{22-24}$ Small hydrophobic and uncharged molecules, and also gasses, are termed as permeant molecules ${ }^{25}$, as these can diffuse through biological membranes freely down their electrochemical gradient. ${ }^{26}$ Charged molecules, such as amino acids, nucleosides, carbohydrates, and ions, can be driven by difference in electric potential or their concentration differences to move through the membrane when assisted by specific transporter proteins, or channels, in the process known as 'facilitated diffusion'. On the other hand, the transport of molecules and ions across biological membranes against their electrochemical gradient requires the input of energy, and is therefore referred to as active transport. ${ }^{13}$ The build-up of concentration gradients of molecules and ions across biological membranes proceeds exclusively through transmembrane protein systems, such as ion pumps and the ATP-binding cassette $(\mathrm{ABC})$ transporters, which are usually powered by ATP hydrolysis. ${ }^{27}$ Large and charged molecules, such as proteins, nucleic acids (e.g., DNA, RNA), and diverse synthetic drugs, cannot cross cell membranes per se at all. Numerous therapeutic molecules are of this nature, and therefore to get them into cells, where they function, different techniques have been developed to increase the plasma membrane permeability.

\section{3. Ways to Increase the Permeability of the Plasma Membrane}

The main physiological role of the cell plasma membrane is to control and regulate the flux of molecules or ions into and out of the cell. The selectivity of the plasma membrane for the passage of molecules or ions is very high, and therefore for therapeutic or biotechnological reasons, the aim is to create procedures that enable the manipulation of transmembrane transport, ideally in a relatively controlled fashion. Caution is however needed, as treatments to increase the permeability of the plasma membrane can also result in increased molecular efflux, which can then induce cell death. On the other hand, the efflux of molecules from cells can also be exploited under certain conditions in biotechnology, to extract bioproducts. ${ }^{28}$

Several methods to increase the permeability of biological membranes have been described. Table 1 gives the main characteristics and applications of the main biochemical (lipid and polymer particles, microbubbles), biological (viral), and physical (ultrasound, electroporation) methods for plasma-membrane permeabilization.

In this article, the focus is on electroporation, as the alteration of the cell membrane permeability induced by exposure to an externally applied electric field. Due to the membrane exposure to pulsed electric field, pores are formed in the cell membrane and increase its conductance for various hydrophilic molecules, such as peptides, nu-

Table 1. Different methods used to manipulate cell-membrane permeability.

\begin{tabular}{|c|c|c|c|}
\hline Method & Main characteristics & Applications & References \\
\hline $\begin{array}{l}\text { Sonoporation mediated } \\
\text { by microbubbles }\end{array}$ & $\begin{array}{l}\text { Transient perforation of the plasma } \\
\text { membrane; noninvasive }\end{array}$ & Drug and gene delivery & $29-31$ \\
\hline $\begin{array}{l}\text { Lipid or lipid-like vesicle } \\
\text { fusion }\end{array}$ & $\begin{array}{l}\text { Oral delivery; protects a loaded drug; } \\
\text { release of a drug in a controlled way }\end{array}$ & Drug delivery & 32,33 \\
\hline Virus fusion & Injection; can trigger an immune response & Gene delivery & 34 \\
\hline Cytolytic toxins & Bacterial cytotoxic proteins & Virulence-targeted therapies & 35 \\
\hline Ultrasound & $\begin{array}{l}\text { High intensity focused ultrasound; } \\
\text { generation of cavities due to ultrasound oscillation }\end{array}$ & $\begin{array}{l}\text { Drug and gene delivery; } \\
\text { tissue ablation }\end{array}$ & $36-38$ \\
\hline Electroporation & $\begin{array}{l}\text { High voltage electric pulses; formation } \\
\text { of hydrophilic pores in the plasma membrane }\end{array}$ & $\begin{array}{l}\text { Drug and gene delivery; } \\
\text { tissue ablation }\end{array}$ & $2,7,39$ \\
\hline
\end{tabular}


cleic acids, and drug molecules. Electroporation is used in medicine and biotechnology for the delivery of drugs or genes into cells, for tissue ablation, for extraction of bioproducts from cells, and for microbial inactivation in food preservation. ${ }^{3,40-42}$

\section{Principles of Plasma-Membrane Electroporation}

Electroporation leads to increased permeability of the cell membrane as a consequence of the application of electric pulses. The term electroporation was coined by Neumann and colleagues in $1982 .{ }^{43}$ It originally described the process of electrically induced hydrophilic pore formation in the lipid bilayer (Figure 1).

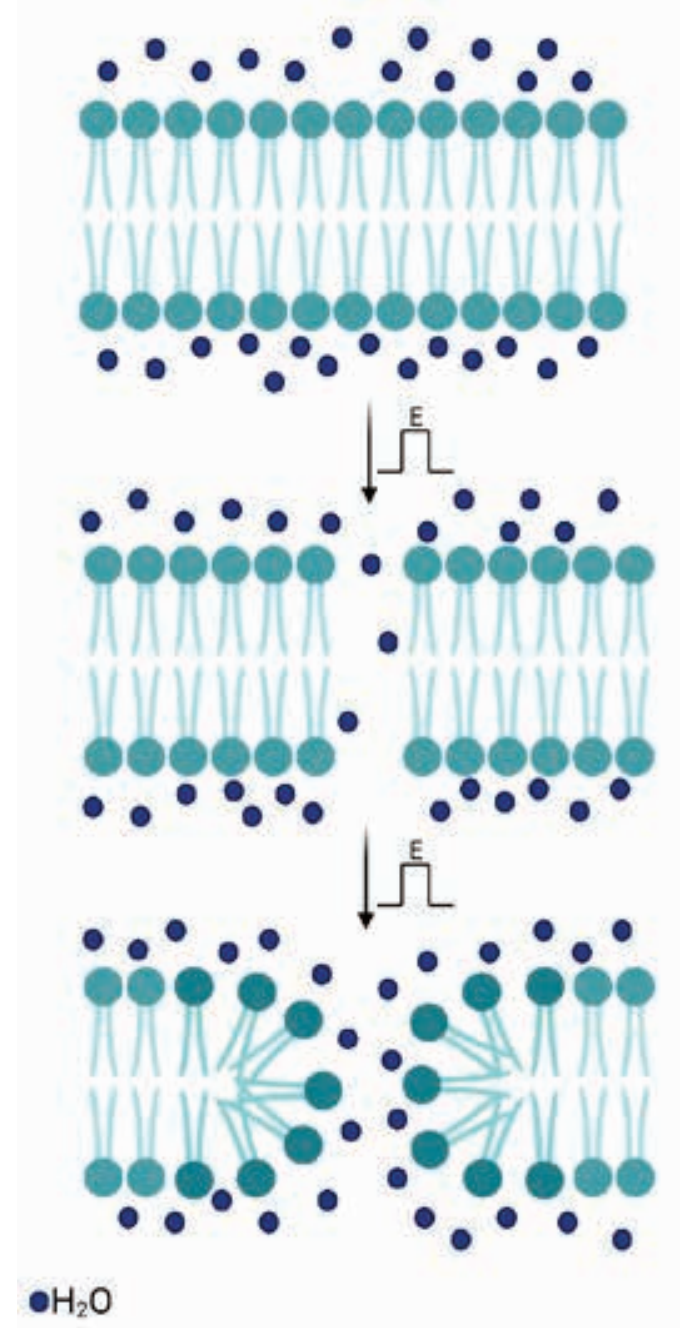

Figure 1. Formation of a hydrophilic pore in the membrane lipid bilayer. Exposure of the membrane to the electric field (E) allows the penetration of water molecules into the lipid bilayer. This induces reorientation of the polar headgroups of the lipids towards the penetrating water molecules, which ultimately leads to the formation of a hydrophilic pore, i.e. electroporation.
From the electrical point of view, the cell membrane can be regarded as a thin insulation sheet that is surrounded on both sides by an electrolyte. The transmembrane voltage is the difference in the electric potentials between outside and inside of the cell, which is due to the difference between the intracellular and extracellular ion concentrations. Specifically, different ions are present on either side of the membrane plane and have a concentration gradient across it, which results in formation of the transmembrane voltage. An electrical double layer is formed when a charged membrane plane is in contact with an electrolyte solution consisting of charged ions and oriented dipoles, resulting in accumulation of oppositely charged ions (counter-ions) and depletion of ions with the same charge (co-ions). ${ }^{44-46}$ Membrane itself has a net charge, which is dependent on the lipid composition, due to charged lipid head groups. The hydrophobic region of the membrane has a zero net charge. When the membrane is surrounded by an electrolyte, an interface forms, due to the separation of charged ions on either side of the membrane causing the formation of electrical double layer and consequently the transmembrane voltage. ${ }^{4-49}$ In the resting state, the cell membrane acquires the so called 'resting (trans)membrane voltage, which is typically between $-40 \mathrm{mV}$ and $-70 \mathrm{mV}{ }^{1}$

Due to the opening or closing of ion channels in the cell membrane, the resting voltage can shift to more negative or more positive values, i.e., the membrane becomes hyperpolarized or depolarized. ${ }^{13}$ When a cell is exposed to an external electric field, an induced transmembrane voltage is superimposed on the existing resting transmembrane voltage. The resting transmembrane voltage is always different from zero, and is equal all around the cell since the membrane is an isotropic dielectric medium with constant dielectric permittivity. On the other hand, the induced transmembrane voltage is present only for the duration of the external electric pulse, and it is anisotropic, or dependent on the position on the cell membrane..$^{50}$ Due to this induced transmembrane voltage, the structure and function of the cell membrane is locally modified. ${ }^{1}$ The membrane undergoes electrical breakdown, which results in increased permeability for virtually all molecules. As the cell membrane behaves as a two-dimensional liquid, it can return to its pre-breakdown state, and thus the cell can survive. In such a case, we talk about reversible electroporation. However, when the exposure of the cell membrane to an electric field is very intensive, the cell will die, even if the membrane manages to reseal. This type of electroporation is referred to as irreversible (IRE). ${ }^{40,51}$

In electroporation, three general levels have been defined: (1) no detectable electroporation; (2) reversible electroporation; and (3) IRE. The range over which each of these occur is characterized by the strength of the external electric field applied $(\mathrm{V} / \mathrm{cm})$ and the duration of exposure (seconds) to it. To achieve electroporation, longer pulse durations require lower electric field strengths. For example, for a pulse of 1 millisecond, no detectable elec- 
troporation is seen from $0 \mathrm{~V} / \mathrm{cm}$ to $250 \mathrm{~V} / \mathrm{cm}$, reversible electroporation occurs between $250 \mathrm{~V} / \mathrm{cm}$ and $1750 \mathrm{~V} / \mathrm{cm}$, and IRE occurs above $1750 \mathrm{~V} / \mathrm{cm} .{ }^{52}$ In the first range for no detectable electroporation, if pores are formed, they are too small and/or too unstable to be detected. For reversible electroporation, the pores can provide a temporary pathway for molecular transport across the membrane, although once the electric pulse ceases, the membrane gradually reseals, the induced transport stops and most of these cells will survive and remain viable. For IRE, the membrane may not reseal or will reseal too slowly for cell to maintain its viability. These cells then lose their integrity, with the release of their contents, and ultimately die. ${ }^{51,53}$

From a mechanistic point of view, electroporation is best described by the theory of hydrophilic pore formation. The external electric field induces a drop in the electric potential across the lipid bilayer, which leads to the formation of hydrophilic pores in the bilayer. ${ }^{43}$ Both, theoretical considerations and molecular dynamics simulations suggest that electroporation is initiated by the penetration of water molecules into the hydrophobic core domain of the lipid bilayer, which then causes a re-orientation of the adjacent lipid molecules, whereby their polar headgroups will follow the direction of the invading water molecules (Figure 1) ${ }^{54}$ First, single water molecules penetrate the hydrophobic core of the bilayer due to local defects in the lipid headgroup region. Then, these so-called water fingers expand into the hydrophobic core of the bilayer, and firstly form a hydrophobic pore. ${ }^{1,54,55}$ Subsequently, these pores are stabilized by reorientation of the lipid headgroups adjacent to the water molecules, thus stabilizing the pore into its hydrophilic state and allowing more water, as well as other polar molecules and ions, to enter. ${ }^{40,55,56}$ After the electric field is eliminated, the pores that are formed and stabilized have lifetimes from milliseconds to minutes (Table 2). ${ }^{1}$ As indicated experimentally and theoretically, stability of the pores can be increased by intercalation of different molecules in the lipid bilayer. ${ }^{57-59}$

Furthermore, membrane tension and mechanical stress can also play a role in formation of hydrophilic pores in the lipid bilayer. ${ }^{60-62}$ Applied electric field can cause lateral stress to the membrane influencing interfacial tension and pore formation..$^{55}$ With a reduction in membrane tension in the lateral plane a decrease in the interaction be- tween the phospholipid molecules occurs and with it an increase in ion permeability. ${ }^{63}$

\section{Effects of an Electric Field on Cellular Structures}

Cells consist of many different components, and an external electric field can affect these in different ways. Some of these alterations are necessary for the cell membrane electroporation to occur. However, others are not wanted, as they can induce cell death. Thus, attempts are made to reduce the unwanted effects as much as possible. We are focusing here on the effects of an external electric field on three main cellular structures: the lipids that form the plasma membrane; the proteins associated with the plasma membrane; and the cytoskeleton that lies under the plasma membrane and imposes shape to the cell (Figure 2).

\section{1. Effects of an Electric Field on the Lipid Bilayer}

Application of electric pulses induces the formation of transient hydrophilic transmembrane pores in lipid bilayers. However, this does not fully describe the sustained increased permeability of the lipid bilayer, which can last long after the electric field has been removed. One possibility to explain such effects is peroxidation of lipids during the electroporation, which changes the chemical structure of the membrane to remain permeable. ${ }^{64,65}$

Lipid peroxidation is a chemical reaction between lipid molecules and oxygen that results in the formation of unstable lipid peroxides. This can occur for lipid structures under stress, such as in the presence of reactive oxygen species (ROS). Lipid peroxidation is a free-radical chain reaction that can generate various products, most of which are harmful for the cell. ${ }^{66,67}$ The unsaturated fatty acid chains of the lipid molecules are the main targets of the peroxidation. Oxidized lipid tails become more polar and can also shorten in length. These changes can disrupt the structure of the lipid bilayer, to thus alter its fluidity, and consequently increase the permeability of the cell membrane $^{68}$ The membrane becomes thinner, less densely

Table 2. Steps in the formation of hydrophilic pores during electroporation of a lipid bilayer. ${ }^{1}$

\begin{tabular}{|c|c|c|}
\hline Step & Main characteristics & Duration \\
\hline Initiation & $\begin{array}{l}\text { Membrane electrical conductivity and } \\
\text { permeability start to increase }\end{array}$ & $\begin{array}{l}\text { Nanoseconds (conductivity for electric current); } \\
\text { microseconds (permeability for ions and molecules) }\end{array}$ \\
\hline Expansion & Conductivity and permeability persist and intensify & Until the end of the pulse (up to milliseconds) \\
\hline Partial recovery & $\begin{array}{l}\text { After the external voltage ceases, membrane } \\
\text { conductivity and permeability decrease rapidly, } \\
\text { but not to zero (i.e. not to the pre-poration state) }\end{array}$ & $\begin{array}{l}\text { Microseconds (conductivity for electric current); } \\
\text { milliseconds (permeability for ions and molecules) }\end{array}$ \\
\hline Resealing & $\begin{array}{l}\text { The membrane recovers to its physiological state } \\
\text { of impermeability }\end{array}$ & Seconds to minutes \\
\hline Memory & $\begin{array}{l}\text { The cell can show alterations to stressors before } \\
\text { finally returning to its normal state }\end{array}$ & Hours \\
\hline
\end{tabular}


(a)

\section{Lipid oxidation}
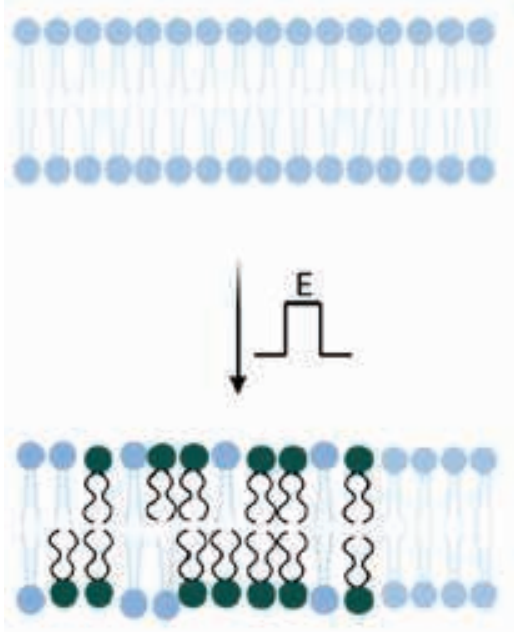

(b)

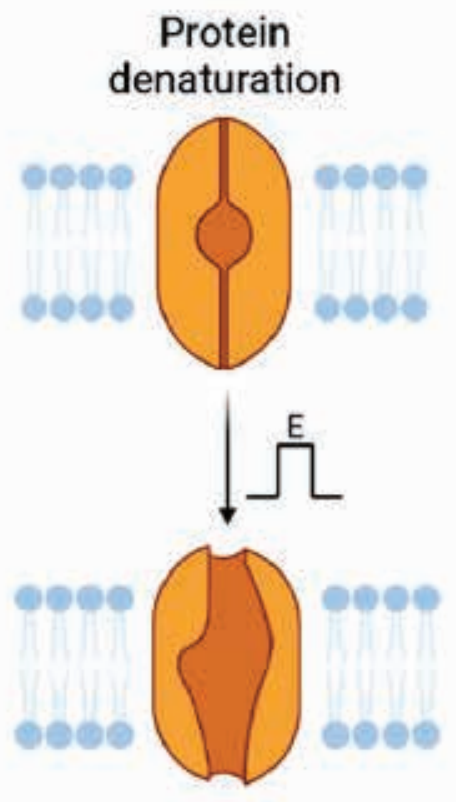

(c)

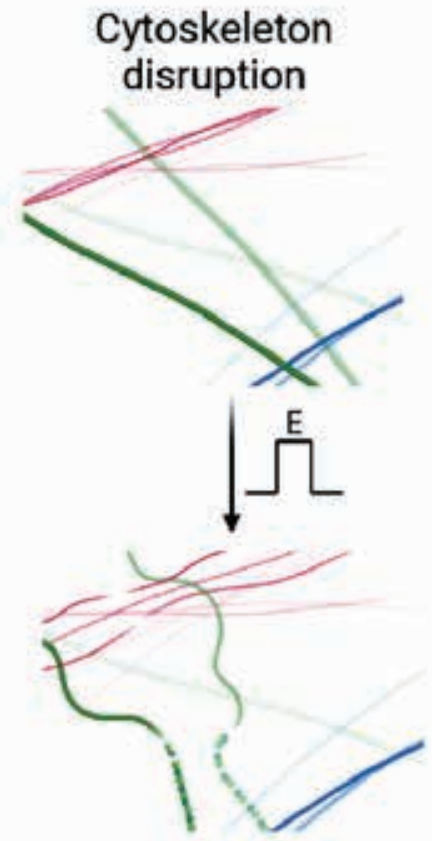

Figure 2. The effects of electric field (E) on the main cellular components. (a) The process of electroporation can induce oxidation of the lipids in the cell membrane. (b) An external electric field can induce localized heating in membrane proteins, which can lead to their reversible or irreversible denaturation, with a temporary or permanent loss of their function, respectively. (c) During electroporation, the cytoskeleton often depolymerizes and detaches from the plasma membrane (Figure adapted from reference 1).

packed, and with lower internal order. Such lipid bilayers are no longer stable and are prone to undergo lateral phase separation. The cumulative result here is that the physiological functions of the cell membrane are altered, which can lead to cell damage, and even to cell death. ${ }^{69-71}$

It has been reported that electroporation induces lipid peroxidation in bacteria, plant cells, and mammalian cells, as well as in liposomes made from polyunsaturated phospholipids. ${ }^{1}$ The origins of ROS are diverse. It has been suggested that electric pulses can generate ROS by triggering redox reactions in the water medium, on the membrane surface, and at the electrode-electrolyte interface. ${ }^{72,73}$ However, electric pulses initiate creation of ROS also inside the lipid bilayer and in the cell. In addition, there are always some ROS already present in the system. ${ }^{74,75}$ All ROS, no matter their origin, can result in peroxidation of lipids during electroporation; however, as ROS are short-lived, only those generated in close proximity to the cell membrane will cause lipid damage. It has been demonstrated that ROS peroxidize only the parts of the membrane that are electropermeabilized. These reactions reach their peak a few seconds after application of electric pulses, and then gradually diminish. ${ }^{76}$

\section{2. Effects of an Electric Field on the Membrane Proteins}

Membrane proteins are molecules associated with (i.e., peripheral) or embedded in (i.e., integral) the lipid bilayer of the cell membrane, and they are mainly responsible for all of the specific functions of the biological membranes.

Cell membrane electroporation affects membrane proteins to different extents, where the worst case scenario leads to their inactivation by denaturation, due to the local increase in temperature induced by the electric pulses. ${ }^{77}$ For example, it was shown that exposure of cells to electric pulses increased the conductivity of transmembrane $\mathrm{Na}^{+} /$ $\mathrm{K}^{+}$-ATPases ${ }^{1}$ and decreased transmembrane ionic currents through voltage-gated ion channels. ${ }^{78}$ Gating potentials of voltage-gated ion channels are in the range of $50 \mathrm{mV}$. Therefore, when electric pulses are applied, these channels will open and can experience very large ion currents. This can also inflict irreversible damage to the channel proteins as a result of the local Joule heating or chemical modifications. ${ }^{79}$ The recovery of damaged membrane proteins is much slower than their opening and closing. While channel closing occurs in microseconds, their opening can take even tens of minutes. ${ }^{79}$ The consequences for the cell can therefore be serious, and even fatal.

\section{3. Effects of an Electric Field on the Cytoskeleton}

The cytoskeleton is a cytoplasmic protein structure that is attached under the cell plasma membrane. As it is attached to the plasma membrane, it shapes the cell and has important roles in cell adhesion and migration. The 
main components of the cytoskeleton are microfilaments, intermediate filaments, and microtubules. ${ }^{13}$

The application of electric pulses can affect the integrity of the cytoskeleton. Exposure of cells to electric pulses can disrupt the network of microfilaments and microtubules. These effects are voltage-dependent and reversible, as the cytoskeleton can fully recover within hours without significant loss of cell viability. ${ }^{1,80}$ The disruption of microfilaments was shown to even protect the cell from being killed by external electric pulses. ${ }^{81}$ Electroporation of vesicles with actin filaments showed that membrane rigidification occurs, which blocks any large deformation of the vesicles, and prevents the formation of large membrane pores. ${ }^{82}$ The mechanism of cytoskeleton disruption includes conformational changes and electromechanical processes, although it remains not entirely clear to date. ${ }^{83,84}$ Atomic force microscopy has revealed a decrease in membrane stiffness, leading to the rippling and destabilization of microfilaments. The main reason for the morphological changes observed was shown to be the impaired attachment of the cytoskeleton to the cell membrane. Electroporation often results in cell swelling due to the induced osmotic imbalance, and the resulting swelling force is an important factor in the dislocation of the cytoskeleton from the membrane. ${ }^{1}$

\section{Advantages and Disadvantages of Cell Electroporation}

Electroporation is an efficient method for the manipulation of cell membrane permeability. It can be applied to all types of cells, and no matter which stage of the cell cycle they are in. Its efficiency depends on the size of the cell, as stronger electric fields are required for induction of pore formation in smaller cells than in larger cells. Moreover, the electrical properties of the tissue also greatly influence the electroporation process, such as its conductivity. ${ }^{85}$ As the transport of materials into and out of electroporated cells is not specific, an ionic imbalance can occur, which can be harmful for the cell. Thus, for each specific application of electroporation, the electric pulse parameters need to be appropriately adjusted to minimize unwanted cell damage, or even cell death. ${ }^{53}$

The most widely used applications of electroporation in medicine, electrochemotherapy (ECT), electro-transfer of genes (GET), and irreversible electroporation (IRE) for tissue ablation are illustrated in Figure 3.

\section{1. Electrochemotherapy}

Electrochemotherapy (ECT) is a local treatment that includes chemotherapy followed by tumor-directed elec-

\section{(a) Electrochemotherapy}
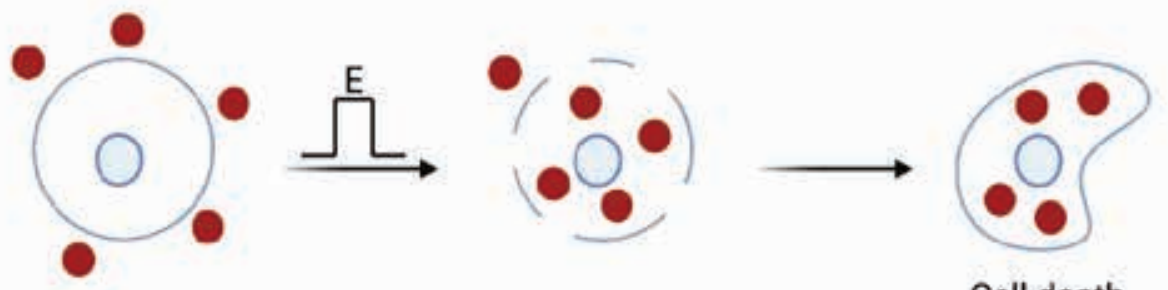

Cell death

\section{(b) Gene electrotransfer}
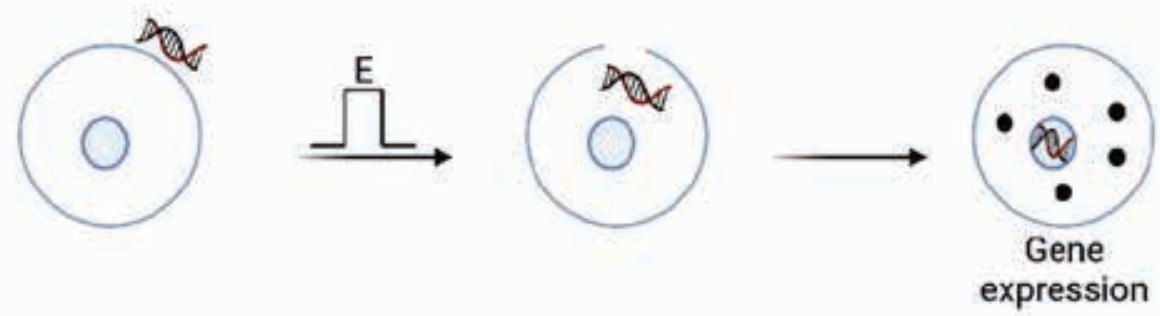

(c) IRE ablation
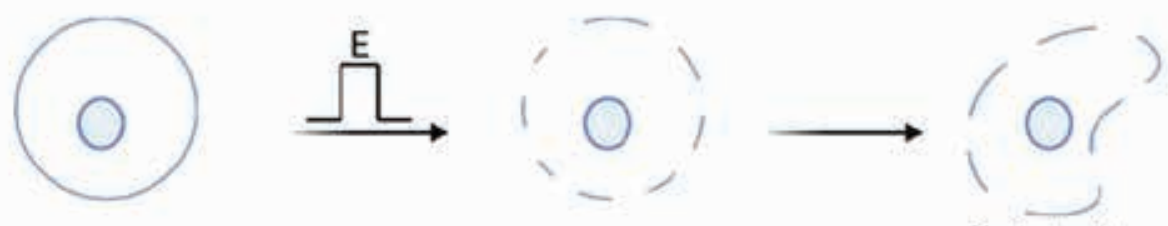

Cell death

Figure 3. The main applications of electroporation in medicine. (a) Electrochemotherapy uses electroporation to increase the uptake of chemotherapeutic drugs into cells, thus boosting their cytotoxic effects. (b) Gene electrotransfer uses electroporation to transfer DNA or RNA molecules into cells, to induce expression of the desired proteins. (c) Irreversible electroporation (IRE) causes cell death and is used to nonthermally ablate tissue (Figure adapted from reference 86). 
tric pulses, to increase the drug delivery into the malignant cells. Electric pulses are applied through metal plate or needle electrodes, to permeabilize the membranes of the cells, and hence to increase the uptake and effectiveness of the drug that was injected prior to the application of the electric pulses. ${ }^{87}$

Electrochemotherapy is simple and easy to perform. It is also a relatively inexpensive treatment. To perform ECT, we need an electric pulse generator (i.e., an electroporator) and suitable electrodes. The treatment can be performed on practically any part of the body. After the treatment, patients do not require special care, nor post-treatment medication. The main advantage of ECT when compared to other techniques is that it combines chemotherapy and the application of electric pulses. The targeted cells die in a more controlled manner, which results in slower shrinkage of the tumor, without development of massive necrosis that represents a major burden for patients and is accompanied by the risk of complications, such as infections. ${ }^{88}$

As well as these advantages, ECT also has some disadvantages. One of these is the pain that patients can experience during the application of the electric pulses as well as muscle contraction. ${ }^{85}$ The factors that can limit the use of ECT include the size of the tumor ${ }^{89}$ and difficult accessibility of a tumor by electrodes For safety reasons, ECT is currently contraindicated for patients with cardiac pacemakers and patients on anticoagulant therapy. ${ }^{3,90}$

\section{2. Gene Electrotransfer}

Gene electrotransfer (GET) uses high-voltage electric pulses to deliver DNA or RNA molecules into cells. In oncology, this is used to induce anticancer effects in tumor cells. ${ }^{4,6}$ GET can also be used for DNA or RNA vaccination, or for gene therapy, as it improves the expression of pertinent proteins. ${ }^{91}$ GET can be used to treat cardiovascular, autoimmune, and infectious diseases. Two specific benefits of GET are that it does not induce unwanted specific immunity, and that it lowers the risk of integration of therapeutic nucleic acids into the host genome, or their environmental spread. ${ }^{6}$ Nowadays GET is among the most promising nonviral methods for gene delivery to cells, due to its safety, efficacy, flexibility, ease of application, and relatively low cost. ${ }^{4,92}$

The main obstacle against the more widespread use of GET, particularly in human medicine ${ }^{2}$, is that when applied in vivo, there can be substantial increases in the local temperature and large changes in the $\mathrm{pH}$ close to the electrodes, both of which reduce the efficacy of the therapy. ${ }^{4,92}$

\section{3. Irreversible Electroporation Ablation}

Electroporation, as IRE, is used as a minimally invasive surgical technique for tissue ablation. ${ }^{7}$ With this procedure, it is possible to ablate undesirable tissue in a controlled and precise manner, without damaging the surrounding critical structures. ${ }^{93}$

There are different minimally invasive methods for tissue ablation, but IRE has certain advantages over these. IRE is not temperature based, and therefore the target tissue can be destroyed without overheating of the tissue. IRE is easy to apply, the local blood flow does not influence its efficacy, and it does not require the use of supportive drugs. It affects only the membranes of living cells, while the extracellular structures remain intact. The result is less scarring and faster healing of the treated tissue. ${ }^{94-96}$ One of the most promising applications of IRE in medicine is for cardiac ablation after atrial fibrillation. ${ }^{97,98}$ This is a catheter-based ablation, and due to its advantages over the contemporary ablation procedures, it has also been recently transferred to human cardiology ${ }^{99,100}$

On the other hand, IRE can damage the entire tissue that is exposed to the electric pulses if the operating parameters are not correctly selected. Therefore, meticulous treatment planning and setting of the correct electroporation parameters are important, to avoid such damage. ${ }^{101}$

\section{The Challenges Ahead}

Electroporation of biomembranes has been studied and developed over the past 40 years; nevertheless, there remain some challenges for further improvement of this methodology.

One fundamental challenge that remains to be resolved for biomembrane electroporation is to identify the underlying molecular mechanisms. Only full understanding of the phenomenon at molecular level will allow unraveling its full potential and its reliable control. For example, the contribution of electric pulses to increased cell membrane permeability due to lipid peroxidation and protein modifications are far from being well understood today.

Preclinical and clinical trials have confirmed the great potential for electroporation-based treatments for cancer and gene therapy, as well as in tissue ablation. However, it is evident that there remains room for further technical improvements to increase the precision and specificity of these treatments, one of the possibilities is through the use of nanoparticles for enhanced electroporation efficiency. ${ }^{102}$ Furthermore, the reduction or elimination of the serious side effects that sometimes occur is of great importance. ${ }^{6,85,103}$ In this context, the processes that occur directly at the electrodes inserted into the tissue during pulse applications need to be better controlled, such as the electrochemical reactions, bubble formation, and local large changes in $\mathrm{pH}$.

Last, but not least, a major problem for the use of electroporation in medicine that awaits resolution is reduction of the intensity and the extent of muscle contraction during the treatments. This would attenuate or even 
eliminate the pain that treated patients experience today, without the need for muscle relaxants. ${ }^{87}$ In this respect, trials that are investigating high-frequency bipolar electroporation pulses appear to be very promising. ${ }^{104-107}$

\section{Acknowledgments}

This work was funded by the Slovenian Research Agency grants P1-0207 (to I.K.), P2-0249 (to D.M. and P.K.) and junior researcher funding grant P2-0249 (to K.B.).

\section{References}

1. Kotnik, T.; Rems, L.; Tarek, M.; Miklavčič, D. Membrane Electroporation and Electropermeabilization: Mechanisms and Models. Annu. Rev. Biophys. 2019, 48 (1), 63-91.

DOI:10.1146/annurev-biophys-052118-115451

2. Geboers, B.; Scheffer, H. J.; Graybill, P. M.; Ruarus, A. H.; Nieuwenhuizen, S.; Puijk, R. S.; van den Tol, P. M.; Davalos, R. V.; Rubinsky, B.; de Gruijl, T. D.; Miklavčič, D.; Meijerink, M. R. High-Voltage Electrical Pulses in Oncology: Irreversible Electroporation, Electrochemotherapy, Gene Electrotransfer, Electrofusion, and Electroimmunotherapy. Radiology 2020, 295 (2), 254-272. DOI:10.1148/radiol.2020192190

3. Serša, G.; Miklavčič, D.; Čemažar, M.; Rudolf, Z.; Pucihar, G.; Snoj, M. Electrochemotherapy in Treatment of Tumours. Eur. J. Surg. Oncol. EJSO 2008, 34 (2), 232-240.

DOI:10.1016/j.ejso.2007.05.016

4. Rosazza, C.; Haberl Meglič, S.; Zumbusch, A.; Rols, M.-P.; Miklavčič, D. Gene Electrotransfer: A Mechanistic Perspective. Curr. Gene Ther. 2016, 16 (2), 98-129.

DOI:10.2174/1566523216666160331130040

5. Rols, M.-P. Electropermeabilization, a Physical Method for the Delivery of Therapeutic Molecules into Cells. Biochim. Biophys. Acta BBA - Biomembr. 2006, 1758 (3), 423-428.

DOI:10.1016/j.bbamem.2006.01.005

6. Lambricht, L.; Lopes, A.; Kos, S.; Serša, G.; Préat, V.; Vandermeulen, G. Clinical Potential of Electroporation for Gene Therapy and DNA Vaccine Delivery. Expert Opin. Drug Deliv. 2016, 13 (2), 295-310.

DOI:10.1517/17425247.2016.1121990

7. Davalos, R. V.; Mir, I. L. M.; Rubinsky, B. Tissue Ablation with Irreversible Electroporation. Ann. Biomed. Eng. 2005, 33 (2), 223-231. DOI:10.1007/s10439-005-8981-8

8. van Es, R.; Konings, M. K.; Du Pré, B. C.; Neven, K.; van Wessel, H.; van Driel, V. J. H. M.; Westra, A. H.; Doevendans, P. A. F.; Wittkampf, F. H. M. High-Frequency Irreversible Electroporation for Cardiac Ablation Using an Asymmetrical Waveform. Biomed. Eng. OnLine 2019, 18 (1), 75.

DOI:10.1186/s12938-019-0693-7

9. McBride, S.; Avazzadeh, S.; Wheatley, A. M.; O’Brien, B.; Coffey, K.; Elahi, A.; O’Halloran, M.; Quinlan, L. R. Ablation Modalities for Therapeutic Intervention in Arrhythmia-Related Cardiovascular Disease: Focus on Electroporation. J.
Clin. Med. 2021, 10 (12), 2657. DOI:10.3390/jcm10122657

10. Mahnič-Kalamiza, S.; Vorobiev, E.; Miklavčič, D. Electroporation in Food Processing and Biorefinery. J. Membr. Biol. 2014, 247. DOI:10.1007/s00232-014-9737-x

11. Genovese, J.; Kranjc, M.; Serša, I.; Petracci, M.; Rocculi, P.; Miklavčič, D.; Mahnič-Kalamiza, S. PEF-Treated Plant and Animal Tissues: Insights by Approaching with Different Electroporation Assessment Methods. Innov. Food Sci. Emerg. Technol. 2021, 74, 102872.

DOI:10.1016/j.ifset.2021.102872

12. Kim, K.; Lee, W. G. Electroporation for Nanomedicine: A Review. J. Mater. Chem. B 2017, 5 (15), 2726-2738. DOI:10.1039/C7TB00038C

13. Alberts, B.; Johnson, A.; Lewis, J.; Raff, M.; Roberts, K.; Walter, P. The Lipid Bilayer. Mol. Biol. Cell 4th Ed. 2002.

14. Lodish, H.; Berk, A.; Zipursky, S. L.; Matsudaira, P.; Baltimore, D.; Darnell, J. Biomembranes: Structural Organization and Basic Functions. Mol. Cell Biol. 4th Ed. 2000.

15. Cooper, G. M. Structure of the Plasma Membrane. Cell Mol. Approach 2nd Ed. 2000.

16. Gov, N. S. Guided by Curvature: Shaping Cells by Coupling Curved Membrane Proteins and Cytoskeletal Forces. Philos. Trans. R. Soc. Lond. B. Biol. Sci. 2018, 373 (1747), 20170115. DOI:10.1098/rstb.2017.0115

17. Alimohamadi, H.; Smith, A. S.; Nowak, R. B.; Fowler, V. M.; Rangamani, P. Non-Uniform Distribution of Myosin-Mediated Forces Governs Red Blood Cell Membrane Curvature through Tension Modulation. PLOS Comput. Biol. 2020, 16 (5), e1007890. DOI:10.1371/journal.pcbi.1007890

18. Mahapatra, A.; Uysalel, C.; Rangamani, P. The Mechanics and Thermodynamics of Tubule Formation in Biological Membranes. J. Membr. Biol. 2021, 254 (3), 273-291.

DOI:10.1007/s00232-020-00164-9

19. Mesarec, L.; Drab, M.; Penič, S.; Kralj-Iglič, V.; Iglič, A. On the Role of Curved Membrane Nanodomains and Passive and Active Skeleton Forces in the Determination of Cell Shape and Membrane Budding. Int. J. Mol. Sci. 2021, 22 (5), 2348. DOI:10.3390/ijms22052348

20. Berg, J. M.; Tymoczko, J. L.; Stryer, L. There Are Three Common Types of Membrane Lipids. Biochem. 5th Ed. 2002.

21. Marquardt, D.; Heberle, F. A.; Nickels, J. D.; Pabst, G.; Katsaras, J. On Scattered Waves and Lipid Domains: Detecting Membrane Rafts with X-Rays and Neutrons. Soft Matter 2015, 11 (47), 9055-9072. DOI:10.1039/C5SM01807B

22. Przybyło, M.; Drabik, D.; Doskocz, J.; Iglič, A.; Langner, M. The Effect of the Osmotically Active Compound Concentration Difference on the Passive Water and Proton Fluxes across a Lipid Bilayer. Int. J. Mol. Sci. 2021, 22 (20), 11099. DOI:10.3390/ijms222011099

23. Hannesschlaeger, C.; Horner, A.; Pohl, P. Intrinsic Membrane Permeability to Small Molecules. Chem. Rev. 2019, 119 (9), 5922-5953. DOI:10.1021/acs.chemrev.8b00560

24. Martínez-Balbuena, L.; Hernández-Zapata, E.; Santamaría-Holek, I. Onsager's Irreversible Thermodynamics of the Dynamics of Transient Pores in Spherical Lipid Vesicles. Eur. Biophys. J. 2015, 44 (6), 473-481. 


\section{DOI:10.1007/s00249-015-1051-8}

25. Yang, N. J.; Hinner, M. J. Getting Across the Cell Membrane: An Overview for Small Molecules, Peptides, and Proteins. Methods Mol. Biol. Clifton NJ 2015, 1266, 29-53.

DOI:10.1007/978-1-4939-2272-7_3

26. Cooper, G. M. Cell Membranes. Cell Mol. Approach 2nd Ed. 2000.

27. Cooper, G. M. Transport of Small Molecules. Cell Mol. Approach 2nd Ed. 2000.

28. Martínez, J. M.; Delso, C.; Álvarez, I.; Raso, J. Pulsed Electric Field-Assisted Extraction of Valuable Compounds from Microorganisms. Compr. Rev. Food Sci. Food Saf. 2020, 19 (2), 530-552. DOI:10.1111/1541-4337.12512

29. Wang, M.; Zhang, Y.; Cai, C.; Tu, J.; Guo, X.; Zhang, D. Sonoporation-Induced Cell Membrane Permeabilization and Cytoskeleton Disassembly at Varied Acoustic and Microbubble-Cell Parameters. Sci. Rep. 2018, 8 (1), 3885.

DOI:10.1038/s41598-018-22056-8

30. He, C.; Gu, Q.; Zeng, H.; Zhang, H.; Huang, M.; Yang, X.; Xing, J.; Chen, J. Microbubble-Enhanced Cell Membrane Permeability in High Gravity Field. Cell. Mol. Bioeng. 2013, 6 (3), 266-278. DOI:10.1007/s12195-013-0279-6

31. Barak, M.; Katz, Y. Microbubbles: Pathophysiology and Clinical Implications. Chest 2005, 128 (4), 2918-2932.

DOI: $10.1378 /$ chest.128.4.2918

32. Xu, W.; Ling, P.; Zhang, T. Polymeric Micelles, a Promising Drug Delivery System to Enhance Bioavailability of Poorly Water-Soluble Drugs. J. Drug Deliv. 2013, 2013, 340315. DOI:10.1155/2013/340315

33. Guimarães, D.; Cavaco-Paulo, A.; Nogueira, E. Design of Liposomes as Drug Delivery System for Therapeutic Applications. Int. J. Pharm. 2021, 601, 120571.

DOI:10.1016/j.ijpharm.2021.120571

34. Cevher, E.; Sezer, A. D.; Çağlar, E. Ş. Gene Delivery Systems: Recent Progress in Viral and Non-Viral Therapy; IntechOpen, 2012. DOI: $10.5772 / 53392$

35. Anderluh, G.; Sepčić, K.; Turk, T.; Maček, P. Cytolytic Proteins from Cnidarians - an Overview. Acta Chim. Slov. 2011, 58 (4), 724-729.

36. Frenkel, V. Ultrasound Mediated Delivery of Drugs and Genes to Solid Tumors. Adv. Drug Deliv. Rev. 2008, 60 (10), 1193-1208. DOI:10.1016/j.addr.2008.03.007

37. Lawrie, A.; Brisken, A. F.; Francis, S. E.; Tayler, D. I.; Chamberlain, J.; Crossman, D. C.; Cumberland, D. C.; Newman, C. M. Ultrasound Enhances Reporter Gene Expression After Transfection of Vascular Cells In Vitro. Circulation 1999, 99 (20), 2617-2620. DOI:10.1161/01.CIR.99.20.2617

38. Liang, H.-D.; Tang, J.; Halliwell, M. Sonoporation, Drug Delivery, and Gene Therapy. Proc. Inst. Mech. Eng. [H] 2010, 224 (2), 343-361. DOI:10.1243/09544119JEIM565

39. Cukjati, D.; Batiuskaite, D.; André, F.; Miklavčič, D.; Mir, L. M. Real Time Electroporation Control for Accurate and Safe in Vivo Non-Viral Gene Therapy. Bioelectrochemistry 2007, 70 (2), 501-507. DOI:10.1016/j.bioelechem.2006.11.001

40. Kotnik, T.; Kramar, P.; Pucihar, G.; Miklavčič, D.; Tarek, M. Cell Membrane Electroporation- Part 1: The Phenomenon.
IEEE Electr. Insul. Mag. 2012, 28 (5), 14-23.

DOI:10.1109/MEI.2012.6268438

41. Kotnik, T.; Frey, W.; Sack, M.; Haberl Meglič, S.; Peterka, M.; Miklavčič, D. Electroporation-Based Applications in Biotechnology. Trends Biotechnol. 2015, 33 (8), 480-488.

DOI:10.1016/j.tibtech.2015.06.002

42. Muramatsu, T.; Nakamura, A.; Park, H. M. In Vivo Electroporation: A Powerful and Convenient Means of Nonviral Gene Transfer to Tissues of Living Animals (Review). Int. J. Mol. Med. 1998, 1 (1), 55-117. DOI:10.3892/ijmm.1.1.55

43. Neumann, E.; Schaefer-Ridder, M.; Wang, Y.; Hofschneider, P. H. Gene Transfer into Mouse Lyoma Cells by Electroporation in High Electric Fields. EMBO J. 1982, 1 (7), 841-845. DOI:10.1002/j.1460-2075.1982.tb01257.x

44. Franklin, J. C.; Cafiso, D. S.; Flewelling, R. F.; Hubbell, W. L. Probes of Membrane Electrostatics: Synthesis and Voltage-Dependent Partitioning of Negative Hydrophobic Ion Spin Labels in Lipid Vesicles. Biophys. J. 1993, 64 (3), 642653. DOI:10.1016/S0006-3495(93)81423-1

45. Bohinc, K.; Kralj-Iglič, V.; Iglič, A. Thickness of Electrical Double Layer. Effect of Ion Size. Electrochimica Acta 2001, 46 (19), 3033-3040. DOI:10.1016/S0013-4686(01)00525-4

46. Gongadze, E.; Iglič, A. Relative Permittivity in Stern and Diffuse Layers. Acta Chim. Slov. 2014, 61 (2), 241-245.

47. Lebar, A. M.; Velikonja, A.; Kramar, P.; Iglič, A. Internal Configuration and Electric Potential in Planar Negatively Charged Lipid Head Group Region in Contact with Ionic Solution. Bioelectrochemistry Amst. Neth. 2016, 111, 49-56. DOI:10.1016/j.bioelechem.2016.04.006

48. Heinrich, R.; Gaestel, M.; Glaser, R. The Electric Potential Profile across the Erythrocyte Membrane. J. Theor. Biol. 1982, 96 (2), 211-231. DOI:10.1016/0022-5193(82)90222-3

49. Iglič, A.; Gongadze, E.; Kralj-Iglič, V. Differential Capacitance of Electric Double Layer - Influence of Asymmetric Size of Ions, Thickness of Stern Layer and Orientational Ordering of Water Dipoles. Acta Chim. Slov. 2019, 66 (3), 534-541. DOI:10.17344/acsi.2019.5495

50. Kotnik, T.; Pucihar, G.; Miklavčič, D. The Cell in the Electric Field; 2011; pp 19-29. DOI:10.1007/978-1-4419-8363-3_3

51. Batista Napotnik, T.; Polajžer, T.; Miklavčič, D. Cell Death Due to Electroporation - A Review. Bioelectrochemistry 2021, 141, 107871. DOI:10.1016/j.bioelechem.2021.107871

52. Yarmush, M. L.; Golberg, A.; Serša, G.; Kotnik, T.; Miklavčič, D. Electroporation-Based Technologies for Medicine: Principles, Applications, and Challenges. Annu. Rev. Biomed. Eng. 2014, 16 (1), 295-320.

DOI:10.1146/annurev-bioeng-071813-104622

53. Polajžer, T.; Jarm, T.; Miklavčič, D. Analysis of Damage-Associated Molecular Pattern Molecules Due to Electroporation of Cells in Vitro. Radiol. Oncol. 2020, 54 (3), 317-328. DOI:10.2478/raon-2020-0047

54. Rems, L. Lipid Pores: Molecular and Continuum Models. In Handbook of Electroporation; Springer International Publishing: Cham, 2016; pp 1-21.

DOI:10.1007/978-3-319-26779-1_76-1

55. Tarek, M. Membrane Electroporation: A Molecular Dynam- 
ics Simulation. Biophys. J. 2005, 88 (6), 4045-4053.

DOI:10.1529/biophysj.104.050617

56. Dehez, F.; Delemotte, L.; Kramar, P.; Miklavčič, D.; Tarek, M. Evidence of Conducting Hydrophobic Nanopores Across Membranes in Response to an Electric Field. J. Phys. Chem. C 2014, 118 (13), 6752-6757. DOI:10.1021/jp4114865

57. Karatekin, E.; Sandre, O.; Guitouni, H.; Borghi, N.; Puech, P.H.; Brochard-Wyart, F. Cascades of Transient Pores in Giant Vesicles: Line Tension and Transport. Biophys. J. 2003, 84 (3), 1734-1749. DOI:10.1016/S0006-3495(03)74981-9

58. Fošnarič, M.; Kralj-Iglič, V.; Bohinc, K.; Iglič, A.; May, S. Stabilization of Pores in Lipid Bilayers by Anisotropic Inclusions. J. Phys. Chem. B 2003, 107 (45), 12519-12526. DOI:10.1021/jp035035a

59. Kandušer, M.; Fošnarič, M.; Šentjurc, M.; Kralj-Iglič, V.; Hägerstrand, H.; Iglič, A.; Miklavč, D. Effect of Surfactant Polyoxyethylene Glycol (C12E8) on Electroporation of Cell Line DC3F. Colloids Surf. -Physicochem. Eng. Asp. -. A 2003, 214. DOI:10.1016/S0927-7757(02)00410-7

60. Bennett, W. F. D.; Sapay, N.; Tieleman, D. P. Atomistic Simulations of Pore Formation and Closure in Lipid Bilayers. Biophys. J. 2014, 106 (1), 210-219.

DOI:10.1016/j.bpj.2013.11.4486

61. Sandre, O.; Moreaux, L.; Brochard-Wyart, F. Dynamics of Transient Pores in Stretched Vesicles. Proc. Natl. Acad. Sci. 1999, 96 (19), 10591-10596. DOI:10.1073/pnas.96.19.10591

62. Brochard-Wyart, F.; de Gennes, P. G.; Sandre, O. Transient Pores in Stretched Vesicles: Role of Leak-Out. In Simple Views on Condensed Matter; Series in Modern Condensed Matter Physics; WORLD SCIENTIFIC, 2003; Vol. Volume 12, pp 327-346. DOI:10.1142/9789812564849_0038

63. Lewis, T. J. A Model for Bilayer Membrane Electroporation Based on Resultant Electromechanical Stress. IEEE Trans. Dielectr. Electr. Insul. 2003, 10 (5), 769-777.

DOI:10.1109/TDEI.2003.1237326

64. Rems, L.; Viano, M.; Kasimova, M. A.; Miklavčič, D.; Tarek, M. The Contribution of Lipid Peroxidation to Membrane Permeability in Electropermeabilization: A Molecular Dynamics Study. Bioelectrochemistry 2019, 125, 46-57.

DOI:10.1016/j.bioelechem.2018.07.018

65. Wiczew, D.; Szulc, N.; Tarek, M. Molecular Dynamics Simulations of the Effects of Lipid Oxidation on the Permeability of Cell Membranes. Bioelectrochemistry 2021, 141, 107869. DOI:10.1016/j.bioelechem.2021.107869

66. Frankel, E. N. Free Radical Oxidation. In Lipid Oxidation; Elsevier, 2012; pp 15-24. DOI:10.1533/9780857097927.15

67. Girotti, A. W. Mechanisms of Lipid Peroxidation. J. Free Radic. Biol. Med. 1985, 1 (2), 87-95.

DOI:10.1016/0748-5514(85)90011-X

68. Yusupov, M.; Wende, K.; Kupsch, S.; Neyts, E. C.; Reuter, S.; Bogaerts, A. Effect of Head Group and Lipid Tail Oxidation in the Cell Membrane Revealed through Integrated Simulations and Experiments. Sci. Rep. 2017, 7 (1), 5761.

DOI:10.1038/s41598-017-06412-8

69. Parra-Ortiz, E.; Browning, K. L.; Damgaard, L. S. E.; Nordström, R.; Micciulla, S.; Bucciarelli, S.; Malmsten, M. Effects of Oxidation on the Physicochemical Properties of Polyunsaturated Lipid Membranes. J. Colloid Interface Sci. 2019, 538, 404-419. DOI:10.1016/j.jcis.2018.12.007

70. Van der Paal, J.; Neyts, E. C.; Verlackt, C. C. W.; Bogaerts, A. Effect of Lipid Peroxidation on Membrane Permeability of Cancer and Normal Cells Subjected to Oxidative Stress. Chem. Sci. 2016, 7 (1), 489-498. DOI:10.1039/C5SC02311D

71. Neto, A. J. P.; Cordeiro, R. M. Molecular Simulations of the Effects of Phospholipid and Cholesterol Peroxidation on Lipid Membrane Properties. Biochim. Biophys. Acta BBA - Biomembr. 2016, 1858 (9), 2191-2198.

DOI:10.1016/j.bbamem.2016.06.018

72. Chang, D. C.; Reese, T. S. Changes in Membrane Structure Induced by Electroporation as Revealed by Rapid-Freezing Electron Microscopy. Biophys. J. 1990, 58 (1), 1-12.

DOI:10.1016/S0006-3495(90)82348-1

73. Gabriel, B.; Teissie, J. Generation of Reactive-Oxygen Species Induced by Electropermeabilization of Chinese Hamster Ovary Cells and Their Consequence on Cell Viability. Eur. J. Biochem. 1994, 223 (1), 25-33.

DOI:10.1111/j.1432-1033.1994.tb18962.x

74. Breton, M.; Delemotte, L.; Silve, A.; Mir, L. M.; Tarek, M. Transport of SiRNA through Lipid Membranes Driven by Nanosecond Electric Pulses: An Experimental and Computational Study. J. Am. Chem. Soc. 2012, 134 (34), 1393813941. DOI:10.1021/ja3052365

75. Benov, L. C.; Antonov, P. A.; Ribarov, S. R. Oxidative Damage of the Membrane Lipids after Electroporation. Gen. Physiol. Biophys. 1994, 13 (2), 85-97.

76. Teissié, J.; Eynard, N.; Gabriel, B.; Rols, M. P. Electropermeabilization of Cell Membranes. Adv. Drug Deliv. Rev. 1999, 35 (1), 3-19. DOI:10.1016/S0169-409X(98)00060-X

77. Tsong, T. Y. On Electroporation of Cell Membranes and Some Related Phenomena. Bioelectrochem. Bioenerg. 1990, 24 (3), 271-295. DOI:10.1016/0302-4598(90)80028-H

78. Rems, L.; Kasimova, M. A.; Testa, I.; Delemotte, L. Pulsed Electric Fields Can Create Pores in the Voltage Sensors of Voltage-Gated Ion Channels. Biophys. J. 2020, 119 (1), 190205. DOI:10.1016/j.bpj.2020.05.030

79. Tsong, T. Y. Electroporation of Cell Membranes. Biophys. J. 1991, 60 (2), 297-306. DOI:10.1016/S0006-3495(91)82054-9

80. Kanthou, C.; Kranjc, S.; Serša, G.; Tozer, G.; Zupanič, A.; Čemažar, M. The Endothelial Cytoskeleton as a Target of Electroporation-Based Therapies. Mol. Cancer Ther. 2006, 5 (12), 3145-3152. DOI:10.1158/1535-7163.MCT-06-0410

81. Xiao, D.; Tang, L.; Zeng, C.; Wang, J.; Luo, X.; Yao, C.; Sun, C. Effect of Actin Cytoskeleton Disruption on Electric Pulse-Induced Apoptosis and Electroporation in Tumour Cells. Cell Biol. Int. 2011, 35 (2), 99-104. DOI:10.1042/CBI20100464

82. Perrier, D. L.; Vahid, A.; Kathavi, V.; Stam, L.; Rems, L.; Mulla, Y.; Muralidharan, A.; Koenderink, G. H.; Kreutzer, M. T.; Boukany, P. E. Response of an Actin Network in Vesicles under Electric Pulses. Sci. Rep. 2019, 9 (1), 8151.

DOI:10.1038/s41598-019-44613-5

83. Graybill, P. M.; Davalos, R. V. Cytoskeletal Disruption after 
Electroporation and Its Significance to Pulsed Electric Field Therapies. Cancers 2020, 12 (5), 1132.

DOI:10.3390/cancers12051132

84. Kim, H. B.; Lee, S.; Chung, J. H.; Kim, S. N.; Sung, C. K.; Baik, K. Y. Effects of Actin Cytoskeleton Disruption on Electroporation In Vitro. Appl. Biochem. Biotechnol. 2020, 191 (4), 1545-1561. DOI:10.1007/s12010-020-03271-4

85. Bolhassani, A.; Khavari, A.; Orafa, Z. Electroporation - Advantages and Drawbacks for Delivery of Drug, Gene and Vaccine; 2014. DOI: $10.5772 / 58376$

86. Calvet, C.; Mir, L. The Promising Alliance of Anti-Cancer Electrochemotherapy with Immunotherapy. Cancer Metastasis Rev. 2016, 35. DOI:10.1007/s10555-016-9615-3

87. Miklavčič, D.; Mali, B.; Kos, B.; Heller, R.; Serša, G. Electrochemotherapy: From the Drawing Board into Medical Practice. Biomed. Eng. OnLine 2014, 13 (1), 29.

DOI:10.1186/1475-925X-13-29

88. Čemažar, M.; Serša, G. Recent Advances in Electrochemotherapy. Bioelectricity 2019, 1 (4), 204-213.

DOI:10.1089/bioe.2019.0028

89. Serša, G.; Čemažar, M.; Rudolf, Z. Electrochemotherapy: Advantages and Drawbacks in Treatment of Cancer Patients. Cancer Therapy 2003, Vol 1, 133-142.

90. Jarm, T.; Krmac, T.; Magjarević, R.; Kos, B.; Cindrič, H.; Miklavčič, D. Investigation of Safety for Electrochemotherapy and Irreversible Electroporation Ablation Therapies in Patients with Cardiac Pacemakers. Biomed. Eng. OnLine 2020, 19 (1), 85. DOI:10.1186/s12938-020-00827-7

91. Broderick, K. E.; Humeau, L. M. Enhanced Delivery of DNA or RNA Vaccines by Electroporation. In RNA Vaccines; Kramps, T., Elbers, K., Eds.; Methods in Molecular Biology; 2017; Vol. 1499, pp 193-200.

DOI:10.1007/978-1-4939-6481-9_12

92. Potočnik, T.; Miklavčič, D.; Maček Lebar, A. Gene Transfer by Electroporation with High Frequency Bipolar Pulses in Vitro. Bioelectrochemistry 2021, 140, 107803.

DOI:10.1016/j.bioelechem.2021.107803

93. Rubinsky, B. Irreversible Electroporation in Medicine. Technol. Cancer Res. Treat. 2007, 6 (4), 255-259.

DOI: $10.1177 / 153303460700600401$

94. Cindrič, H.; Kos, B.; Miklavčič, D. Ireverzibilna Elektroporacija Kot Metoda Ablacije Mehkih Tkiv: Pregled in Izzivi Pri Uporabi v Kliničnem Okolju. Slov. Med. J. 2021, 90 (1-2), 38-53. DOI:10.6016/ZdravVestn.2954

95. Howard, B.; Haines, D. E.; Verma, A.; Packer, D.; Kirchhof, N.; Barka, N.; Onal, B.; Fraasch, S.; Miklavčič, D.; Stewart, M. T. Reduction in Pulmonary Vein Stenosis and Collateral Damage With Pulsed Field Ablation Compared With Radiofrequency Ablation in a Canine Model. Circ. Arrhythm. Electrophysiol. 2020, 13 (9). DOI:10.1161/CIRCEP.120.008337

96. Bradley, C. J.; Haines, D. E. Pulsed Field Ablation for Pulmonary Vein Isolation in the Treatment of Atrial Fibrillation. J. Cardiovasc. Electrophysiol. 2020, 31 (8), 2136-2147. DOI:10.1111/jce.14414

97. Sugrue, A.; Vaidya, V.; Witt, C.; DeSimone, C. V.; Yasin, O.; Maor, E.; Killu, A. M.; Kapa, S.; McLeod, C. J.; Miklavčič,
D.; Asirvatham, S. J. Irreversible Electroporation for Catheter-Based Cardiac Ablation: A Systematic Review of the Preclinical Experience. J. Interv. Card. Electrophysiol. 2019, 55 (3), 251-265. DOI:10.1007/s10840-019-00574-3

98. Štublar, J.; Žižek, D.; Jan, M.; Jarm, T.; Miklavčič, D. Zdravljenje atrijske fibrilacije s katetrsko ablacijo. Slov. Med. J. 2021, 1-10. DOI:10.6016/ZdravVestn.3078

99. Reddy, V. Y.; Koruth, J.; Jais, P.; Petru, J.; Timko, F.; Skalsky, I.; Hebeler, R.; Labrousse, L.; Barandon, L.; Kralovec, S.; Funosako, M.; Mannuva, B. B.; Sediva, L.; Neuzil, P. Ablation of Atrial Fibrillation With Pulsed Electric Fields: An Ultra-Rapid, Tissue-Selective Modality for Cardiac Ablation. JACC Clin. Electrophysiol. 2018, 4 (8), 987-995.

DOI:10.1016/j.jacep.2018.04.005

100. Loh, P.; van Es, R.; Groen, M. H. A.; Neven, K.; Kassenberg, W.; Wittkampf, F. H. M.; Doevendans, P. A. Pulmonary Vein Isolation With Single Pulse Irreversible Electroporation. Circ. Arrhythm. Electrophysiol. 2020, 13 (10), e008192. DOI:10.1161/CIRCEP.119.008192

101. Silk, M.; Tahour, D.; Srimathveeravalli, G.; Solomon, S. B.; Thornton, R. H. The State of Irreversible Electroporation in Interventional Oncology. Semin. Interv. Radiol. 2014, 31 (02), 111-117. DOI:10.1055/s-0034-1373785

102. Zu, Y.; Huang, S.; Liao, W.-C.; Lu, Y.; Wang, S. Gold Nanoparticles Enhanced Electroporation for Mammalian Cell Transfection. J. Biomed. Nanotechnol. 2014, 10, 982-992. DOI:10.1166/jbn.2014.1797

103. Campana, L. G.; Edhemovic, I.; Soden, D.; Perrone, A. M.; Scarpa, M.; Campanacci, L.; Cemazar, M.; Valpione, S.; Miklavčič, D.; Mocellin, S.; Sieni, E.; Serša, G. Electrochemotherapy - Emerging Applications Technical Advances, New Indications, Combined Approaches, and Multi-Institutional Collaboration. Eur. J. Surg. Oncol. 2019, 45 (2), 92-102. DOI:10.1016/j.ejso.2018.11.023

104. Mahnič-Kalamiza, S.; Miklavčič, D. Scratching the Electrode Surface: Insights into a High-Voltage Pulsed-Field Application from in Vitro \& in Silico Studies in Indifferent Fluid. Electrochimica Acta 2020, 363, 137187.

DOI:10.1016/j.electacta.2020.137187

105. Sweeney, D.; Reberšek, M.; Dermol-Černe, J.; Rems, L.; Miklavčič, D.; Davalos, R. Quantification of Cell Membrane Permeability Induced by Monopolar and High Frequency Bipolar Bursts of Electrical Pulses. Biochim. Biophys. Acta BBA - Biomembr. 2016, 1858.

DOI:10.1016/j.bbamem.2016.06.024

106. Scuderi, M.; Reberšek, M.; Miklavčič, D.; Dermol-Černe, J. The Use of High-Frequency Short Bipolar Pulses in Cisplatin Electrochemotherapy in Vitro. Radiol. Oncol. 2019, 53 (2), 194-205. DOI:10.2478/raon-2019-0025

107. Dong, S.; Wang, H.; Zhao, Y.; Sun, Y.; Yao, C. First Human Trial of High-Frequency Irreversible Electroporation Therapy for Prostate Cancer. Technol. Cancer Res. Treat. 2018, 17, 1533033818789692. DOI:10.1177/1533033818789692 


\section{Povzetek}

Elektroporacija je metoda, s katero povečamo prepustnost celične membrane z uporabo visokonapetostnih električnih pulzov. Metodo uporabljamo na različnih področjih: v medicini, biotehnologiji in v živilski industriji. Visokonapetostni električni pulzi izzovejo nastanek hidrofilnih por v lipidnem dvosloju celične membrane, ki omogočijo prehajanje molekul, ki sicer membrane ne prehajajo. V članku podajamo pregled osnovnih principov electroporacije ter kritično spregovorimo o prednostih in slabostih te metode. Razpravljamo o učinkih electroporacije na ključne komponente bioloških membran, kot tudi o glavnih uporabah te metode v medicini, o elektrokemoterapiji, vnosu genov v celice in odstranjevanju tkiv. V zaključku predstavimo še najbolj relevantne izzive tega obetavnega področja raziskav. 